\title{
Szerkesztői bevezető
}

Kedves Olvasó!

Az Opus et Educatio online szakmai folyóiratunk 14. számát lapozgathatja. Gazdag tematikával és színes írásokkal készítettük elő nyár folyamán ezt a számunkat. Lapunk neve (Munka és Nevelés) tematikailag is kötelez, ugyanakkor a cikkek érzékeltetik azt a valóságos tartalmi változatosságot, mely a széles tematika sajátossága. A tucatnyi írás most is a hagyományos rovatstruktúrában jelenik meg.

A Tanulmányok rovatban az oktatás általános kereteiben olyan érzékeny, a munka világában is számos összefüggésében aktualitással bíró cikk Perger Mónika és Takács Ildikó „Munkahelyi pszichoterror vizsgálata pedagógusok körében" írása. Akár tematikus blokknak is tekinthető a következő három tanulmány, melyek a tanulás, korunkban egyre differenciáltabb elemzésével, a tapasztalatok értékelésével foglalkoznak. A Zero2Hero fejlesztő projektre utaló írás - Bakonyvári Dávid, Bodnár Gabriella, Szilágyi Brigitta munkája - a felsőoktatásban is egyre komolyabb problémát okozó lemorzsolódás elleni hatékony prevencióként értelmezhető felzárkóztatás tanulásra, eredményességre való hatását elemzi tudományos igényességgel. Ehhez jól kapcsolódik Lakner Szilvia „A szervezeti tanulás új aspektusai a generációk tükrében” írása, mely a tanulással kapcsolatos generációs felfogások értelmezésével foglalkozik. Végül e blokk zárásaként, a teljes életkori spektrumot is átfogva, Kispálné Horváth Mária közleménye a tanulás hatásait a felnőttek mentális jóllétére mért adatok alapján elemzi.

A Munkaügyi Szemle rovatunkban a férfi karriertevezés sajátosságait elemzi három fiatal szerzőnk, Juhász Tímea, Chovan Brigitta, Tóth Arnold. Ehhez tematikailag jól kapcsoldik Dombi Edina és Roszik Dóra tanulmánya, mely „Elhelyezkedési esélyek vizsgálata a Szegedi Tudományegyetem hallgatóinak körében" címmel a felsőoktatás és munkaerőpiac egyik lényeges érintkezési felületét elemzi. Konkrét vállalati jó gyakorlatot szemléltető esettanulmányként is tekinthetünk Hangya Dóra és Mecséri Júlia érdekes írására, mely címében is érzékelteti - „Legyen szerencsénk máskor is” A SINOSZ és a Szerencsejáték Zrt. jó gyakorlata siket és nagyothallók foglalkoztatásában" - az adott rovat küldetését. S e ponton a lap fejlődésével, az adott rovattal kapcsolatos „szolgálati közleménnyel” is szolgálunk: 2016-tól a kiadók közötti megállapodás alapján a témakörben született, a tudományos publikációk követelményeinek megfelelő lektorált tanulmányok megjelenési helye lett az Opus et Educatio open access online fo-lyóirat. Akkor indítottuk a Munkaügyi Szemle elnevezésű rovatunkat, de a munka világa aktuális gyakorlati problémáival és eseményeivel foglalkozó rövidebb írások a www.munkaugyiszemle.hu weboldalon alkalomszerúen továbbra is megjelentek. Egy-egy link látogatottsága, nézettsége különösen ki-emelkedő volt. Érdekes - és a médium múködtetését társadalmi munkában végzők számára örömteli - módon a korábbi olvasók, előfizetők hiányérzetüket fogalmazták meg a rendszeres kiadvány megszűnésével kapcsolatban. Ezért 
felmérve és reálisan számba véve erőforrásainkat 2017 szeptemberétôl, újraindul a folyóirat. Azonban a nagyobb, lektorált tanulmányok gondozását, megjelentetését továbbra is az Opus et Educatio Munkaügyi Szemle rovata látja el

Jelen számunkban az Eszmélés rovatunkban három gyakorló pedagógus írását is közöljük. Chikány Beáta a szakirányú továbbképzés keretében írt egy érdekes dolgozatot, mely alapján kérte fel a szerkesztőség „A kis iskolák települési múvelődést segítő centrum szerepe és hatása” címú közleményének megírására. A téma pedagógiai és múvelődéstörténeti szempontból jelentős, a kistelepülések élete, fennmaradása szempontjából pedig különösen időszerú. Bíró Kinga „Korszerű IKT eszközök alkalmazása az SNI- s tanulók fejlesztésében” írása szintén egy a jövő fejlődési irányit jelentősen befolyásoló tendenciát érzékeltet a szakképzési gyakorlat színteréről. E rovatot egy kifejezetten érdekes a tanítás-tanulás világával közvetve érintkező, de szellemi-fizikai jólétünk, egészségmegőrzésünk szempontjából különösen fontos téma felvetése, ismertetése zárja. Orosz Beáta közleménye: „A digitális technológia megjelenése a sportpiacon, különös tekintettel az okos fitnesztermekre" érzékelteti, hogy nem csupán a szórakoztató elektronika, vagy a professzionális oktatástechnológia kérdésköre foglalkoztatja a pedagógusokat.

Az Opus et Educatio-ban változatlanul folytatjuk a Projektekröl sorozatunkat, Szegedi Eszter „A CroCooS - Előzzük meg a lemorzsolódást! címú projekt gyakorlati eredményei tanárok számára" írása különösen időszerú témával foglalkozik, s egy recenzió is szerepel az olvasásra ajánlott írások között.

Budapest, 2017. szeptember

\section{Benedek András}

főszerkesztő 